\title{
Challenges in teaching English writing skills: Lessons learnt from Indonesian high school English language teachers
}

\author{
NURHARDIYANTI ADAM \\ Sekolah Dasar Negeri 21 Halmahera Selatan \\ nurujiyati@gmail.com \\ ABID \\ Universitas Negeri Gorontalo \\ abid@ung.ac.id \\ YUSNA BANTULU \\ Universitas Negeri Gorontalo \\ yusna.bantulu@ung.ac.id
}

\begin{abstract}
Writing skill, among the four target language skills, is one of the skills that language learners need to master. In teaching this skill, therefore, teachers should take any effort to help learners write using the language they learn correctly. However, in the context of teaching English in Indonesia, particularly the writing skill, teachers often face challenges. The study reported in this article seeks to identify the challenges experienced by several Indonesian English language teachers in teaching English writing skills at VHS, a vocational high school, in Gorontalo, Indonesia. The participants involved were all English language teachers working at the school. Data were collected using interview and observation, and analyzed by using a thematic analysis method. The findings showed that there were four themes describing the teachers' challenges in teaching English writing skills. They were teaching technique-related challenges, teaching time-related challenges, linguistics-related challenges, and learning motivation-related challenges. Even though the teachers are able to cope with the challenges, they still need to explore more strategies in teaching, thus the teaching and learning process can run effectively.
\end{abstract}

Keywords: English writing skill; English teachers; teaching challenges

\section{INTRODUCTION}

English is a foreign language subject that has been taught at schools in Indonesia since the Independence of Indonesia in 1945 (Lie, 2007). The objective of teaching this language is to help Indonesian school students communicate in English and to write fluently in accordance with a given social context (Depdiknas, 2003). However, the objective is not adequately achieved across the schools. It can be seen from the dissimilar outcomes of teaching English every year. This is influenced by some factors of teaching and learning. Yuwono (2005) as cited in Sulistiyo (2016) claimed that the frequently revised curriculum apparently does not consider some factors, such as 
teachers' qualifications, teachers' time availability, the number of students per class, and the availability of resources and facilities. This affects the success of teaching and learning English in Indonesia schools.

One of the issues that arise in English classroom and confront teachers in teaching English is teaching English writing skills. Writing is considered as an important skill. This statement is further supported by the law in Article 23, 2006. It says that the goal of teaching English writing is students are able to express the meaning in the interpersonal and transactional discourse, in the form of recounts, narrative, procedure, descriptive, news item, report, analytical exposition, spoof, explanation, discussion, and review in the context of everyday life (Depdiknas, 2006). It implies that students are expected to write any kinds of the given text. Thus, English teachers are required to provide assistance in increasing students' ability in putting their ideas and opinion into written form in order to achieve the goal of teaching that has been stated before. Therefore, this study aims to identify the challenges experienced by Indonesian English teachers in teaching English writing skills at a VHS in Gorontalo, Indonesia.

\section{LITERATURE REVIEW ENGLISH LANGUAGE TEACHING IN INDONESIA}

In Indonesia, English becomes a compulsory subject. Mattarima and Hamdan (2011) stated that English is a compulsory subject that is being taught at many Indonesian schools. In teaching this language, there are four skills that are included in it. Those are listening, reading, speaking and writing. Writing is crucial in language learning. Time, study, and practice are needed for this skill to be developed. Celce-Murcia (2001) said that writing is ones' capability to express idea with coherence and accuracy as major achievement in writing form which is written in second or foreign language. It means that writing is the written form of one's ideas, opinion, feeling or experience that be written through arranging words, clause, phrase and paragraph in second or foreign language with considering the grammar of the sentences and the correct flow of idea so that the writing can be understandable.

Teacher-centered is among the commonly used method in teaching English in Indonesia. As stated by Mbato (2013), teaching English in Indonesia tends to be teacher-centered, with a strong emphasis on compliance with curriculum and testing. It is because some teachers still act as the center in some schools, even after the change and the implementation of curriculum 2004 (teacher becomes center) to the curriculum 2013 (students become center). This phenomenon happened because the teachers see the students' ability in English and limited motivation to study English, which seems to need the guidance from the teachers. Suryati $(2013$, p.4) noted that students' exposure to English is limited in EFL context, and the classroom is usually the only place they have the opportunity to use English. Thus, the teacher's explanation and instruction may be the only language exposure during which students learn to use language for communication.

\section{TEACHING ENGLISH WRITING SKILLS}

In teaching English writing, the teacher acts a guide. Teacher guides the students to know the text in linguistic and contextual framework (Byrne, 1988, p.16). The teacher provides the guidance and explanation regarding the writing process through their instruction. It can also aid the students in finding out certain strategy to improve their writing skill. According to Cotterall and Cohen (2003) as cited in Abid (2020), a positive contribution of the way students improve writing skills is that 
students can expand their writing skills and get feedback directly from the teacher during their writing process.

\section{CHALLENGES IN TEACHING ENGLISH WRITING SKILLS}

English in EFL context is a complicated and challenging job, which is encountered by native and non-native teachers of English due to different obstacles and web difficulties in teaching English that the teacher struggle with when teaching English in the classroom (Alaamri, 2013, p.1140). This statement implies that teacher do face and handle the challenges in teaching English that are caused by several obstacles and difficulties. Othman (2006) said that challenges in teaching writing is when the process of teaching writing does not show teaching of such a skill. This means that there are some occasions during the process of teaching writing when teacher does not train the students' writing skill, such as; choose the appropriate dictation, use the correct grammar, and use random sentences to organize ideas; whereas teacher is required to help the students in writing so that they could acquire and display the corresponding skill. In teaching writing, teacher has to teach a lot of students with variety of understanding and provide a guide to make them understand with the lesson of writing. The time is also needed to be managed since it is limited even though teaching writing requires a lot of time. Also, teacher needs to be efficient and clever on using the facilities in order to achieve successful teaching.

\section{METHOD}

A qualitative research approach was used in this study. There were two instruments utilized in collecting the data: interview and observation. For the interview, a semi structured interview protocol was used to gather data, while for the observation, the researcher acted as a nonparticipant observer. The participants of this study were the English language teachers of VHS in Gorontalo. There were four English teachers in this school who voluntarily participated in this study. Thematic analysis method was used to analyze the interview and observation data. Thematic analysis is a method used to identify, analyze, organize, and report the themes found in the data (Braun \& Clarke, 2006, p.79).

\section{FINDINGS AND DISCUSSION}

There were four main themes identified which best address the research question of the present study, namely, (1) teaching technique-related challenges, (2) teaching time-related challenges, (3) linguistics-related challenges, and (4) learning motivation-related challenges. The following section presents the findings along with the discussion. Participants' statement and record of field notes in the form of Indonesia and English translation are also included.

\section{TEACHING TECHNIQUE-RELATED CHALLENGES}

For the purpose of this study, teaching technique is defined as how a teacher teaches in a classroom. Based on the result of interview, the teachers gave some various answers about teaching technique. For example, Participant 1 said that they used different techniques based on the students' ability in the class that she taught. There are some classes where the students found it easy to understand the lesson when the teacher used technique that was made based on the lesson plan. However, 
there were also some classes that had a hard time to understand the lesson. Thus, she taught a lesson using techniques that were easy to be understood by the students.

“...Kalau teknik kadang saya mau gunakan teknik yang dibuat di RPP...Biasanya kalau yang di kelas TKJ, APK kita gunakan Problem Base Learning, Discovery Learning mereka bisa cepat tanggap dengan teknik yang kita gunakan. Tapi kalau di kelas-kelas Otomotif, kelas TGB kadang tekniknya kita rubah.Kita ambil yang lebih mudah.” (P4:12)

"...If it is about technique, sometimes I want to use technique that is made in the lesson plan (RPP). Usually, in Computer Engineering (TKJ) class and Office Administration (APK) class, we use Problem Based Leraning, Discovery Learning, they are quick to respond with the technique that we use. However, in Automotive, Building Engineering (TGB) class, sometimes we change the technique. We take the easy one." (Researcher' Translation, P4)

Participant 3 also added that they taught and used different techniques in Computer Engineering (TKJ) major and Automotive major. It was done in order to adapt to the class that they teach. It is because every class possesses different ability. Thus, several techniques were used to make the lessons easier for the students.

“..Jadi untuk mengajar writing di jurusan TKJ, saya biasa minta mereka menulis berdasarkan contoh yang saya berikan mereka bisa tapi kalau di kelas Otomotif saya biasanya cuma minta mereka menulis teks terus minta mereka identifikasi itupun saya harus dampingi terus cuma cara itu yang mereka bisa..." (P3:54)

"..So for teaching writing in Computer Engineering (TKJ) class, I usually ask them to write based on the given example. Despite this, in Automotive class, generally, i ask them to write a text and then ask them to identify it. Moreover continuously assisting them is the only that way they can..." (Researcher's Translation, P3:54)

Information presented in the data above is corresponded with the obtained information from the researcher's observation. Participant 4 taught in class of XI- TSM, on Thursday, November $21^{\text {th }}, 2019$, when they asked and guided the students to find difficult words in the text that was given them and translated the words into Indonesian.

"Guru meminta dan membimbing siswa-siswa untuk menulis kata-kata yang sulit yang mereka temukan di kertas berisi text how to make coffee text kemudian diterjemahkan ke dalam bahasa Indonesia. Menurut saya ini bagus supaya siswa-siswanya dapat menambah kosa kata dalam bahasa inggris dan memudahkan mereka dalam menulis. Serta ini juga bagus karena saat guru tidak pandu seperti itu mereka tidak buat dan cuman bercerita dengan teman mereka." (Fieldnote 4-TSM-11/21/2019-12.45)

"Teacher asked and guided the students to write difficult words that they found in the paper with the text of how to make a coffee on it and then translated it (the words) into Indonesian. This is good because from my perspective, it increases students' English vocabulary and ease them in writing. Besides, this is also a beneficial because the students will not do the task or talk with their friends if the teacher did not guide them" (Researcher's Translation, Fieldnote 4-TSM-11/21/2019-12.45)

The participants' response above showed that teaching technique-related challenges was challenging for the teachers because when they teach in class, they did not use techniques that they had prepared based on lesson plan and change the technique to adapt the students' ability and condition in the class. Wilson (2014) stated that students' different intelligence and background knowledge about the lesson is one of the challenges that teachers face while teaching in the classroom. It is because the using of technique becomes the main point in improving students' English competence. Abid (2019) believes that in the initial stages of teaching praxis, the teacher 
must help the students to practice English that they have learned before, beside students develop their English proficiency level based on the availability of opportunities provided by the teacher.

\section{TEACHING TIME-RELATED CHALLENGES}

Teaching time is defined as how much the time that the teacher and the students need in teaching and learning activities in the classroom. The given time must be sufficient for the teacher to do activities efficiently which is challenging for the teacher to do that because there are a lot of things that the teacher should be considered carefully. The data shows that the availability of time in teaching is challenging for the teachers. For example, Participant 4 explained the important of time in teaching English writing skill. When she gave writing task that is too difficult for her students, they needed more time. Thus, she gives her students time to finish the task in the next meeting.

"Kita lihat, kalau agak gampang untuk mereka buat cukup waktu yang diberikan. Tapi kalau writingnya susah untuk mereka mau buat tidak cukup waktu. Jadi, terpaksa dilanjutkan untuk pertemuan berikutnya." (P1:18)

"The time would be sufficient if the given task was easy enough for them. Meanwhile, if the writing is too difficult for them, the time would not be enough. So, I will continue it in the next meeting" (Researcher's Translation, P1:18)

On the other hand, the allocation time of learning is quite challenging. Two participants shared the same view about it. Participant 1, for instance, perceived that teaching within three hours is better than teaching with the divided time.

"Biasa kan disini ada cuma satu jam, kalau 3 jam bagus juga. Biasa mereka beri 3 jam pelajaran yang dibagi-bagi menjadi 2 jam dan 1 jam pelajaran. Kalau dia 3 jam, materi bisa selesai." (P1:18)

"...Usually it is only one hour, but 3 hours is better. Initially, they (school staff) give 3 hours lesson that were divided into 2 hours and 1 hour lesson. If it is 3 hours, the lesson could be finished." (Researcher's Translation, P1:18)

The data above was supported by result of the researcher's observation to Participant 3. They taught for two hours and it is not enough. It is because at the end of the lesson time, there were some students who did not finish the task. Thus, the participant asked the students to collect in the next meeting and gave scores based on their dedication. Researcher's observation on Wednesday, $20^{\text {th }}$ November 2019, in XI TKJ class:

"Jam pelajaran 2 jam dan sampai jam terakhir ada 4 siswa yang menyelesaikan tugas. Guru melanjutkan ke pertemuan selanjutnya untuk 4 siswa yang belum menyelesaikan tugas. Selain itu guru juga mengingatkan mereka dengan pemotongan nilai serta tugas mereka diselesaikan dan dikumpulkan minggu depan di akhir pertemuan.Menurut saya ini kurang bagus karena guru tidak memperingati siswa-siswa saat mereka mengerjakan tugas/ diawal mereka mengerjakan tugas agar mereka dapat menyelesaikannya tepat waktu. Sehingga di pertemuan berikutnya guru bisa memulai dengan kegiatan yang lain." (Fieldnote 3-TKJ[11/20/2019-11.30)

"Until the end of the 2 lesson's hours, there were 4 students who could not finish the task. The teacher continued to the next meetimg for 4 students who did not finished the task yet. Also, the teacher reminded them about the score cut and their tasks need to be collected in the next meeting at the end of the lesson time. From my personal standpoint, the teacher needs to remind the students to finish their tasks on time so that at the next meeting, teacher could start with another activity. (Researcher's Translation, Fieldnote 3-TKJ[-11/20/2019-11.30) 
The data observation above can be compare with data observation that get from Participant 2 which show teaching three hours more good than time that is divided. Researcher's observation found that Participant 2 can maximize the lesson time. It was because the participant taught for 3 hours and the entire students can finished the task. Researcher's observation on Monday, $18^{\text {th }}$ November 2019, in XI-TAV class:

"Waktu pelajaran 3 jam.Semua siswa menyelesaikan tugas yang diberikan oleh guru.Menurut saya ini bagus karena guru bisa memaksimalkan pengguanan waktu dalam pembelajaran."

(Fieldnote 2-TAV-11/18/2019-10.00)

"The lesson time is 3 hours. All students finished the given task by the teacher. According to my thinking, it is good for the teacher who can maximize the using of time in teaching." (Researcher's Translation, Fieldnote 2-TAV-11/18/2019-10.00)

These participants reported that limited teaching time is challenging for the teacher in teaching English writing in the classroom. It is because the students need more time to finish the tasks. It makes the teachers need more time and strategy to make the students finish their work on time. Thus, the teachers continue the lesson in the next meeting and using different technique of teaching based on the meeting. Abid (2015) found that one of his research participants reported that the given time was not enough for them to practice in the classroom; thus they need to practice by themselves outside classroom situation. Hence, in teaching English writing skills, the teachers need to manage the time with an emphasis for the students to finish their writing task based on the given time by the teacher. As Nguyen (2014) claimed, teachers had to specify the time for the students before they did the exercise. By doing this, the teachers could make the students focus more, or speed up to finish their exercise on time. This would help the teachers have more time during the lesson for other activities or tasks. It was done by the teacher to keep the activities on the track.

\section{LINGUISTICS-RELATED CHALLENGES}

Linguistics-related challenges means teachers' challenges that constrain them to teach English writing to the students who lack of vocabulary, grammar and arranging ideas. The data showed that teachers got challenges in teaching students who had English linguistic-related problems. For example, Participant 1 stated that they faced obstacle when the students were asked to write a long sentence in the form of paragraph. It is because they are lacking of vocabulary. They could not write new sentences correctly. So, the participant let them use internet to help them to write sentences.

“....ada beberapa kosa kata yang masih baru buat mereka jadi itu menjadi kendala kalau mereka diminta untuk menulis kalimat yang agak panjang...dalam bentuk paragraph, terpaksa kita beri tugas dan mereka kalau sudah diberi tugas mereka lihat di internet. Karna mereka punya vocabulary kurang...” (P1:40)

"....Usually, there are some new vocabularies that were unknown to them which are hard for them if they are asked to write a long sentence in a paragraph. Thus, we have to give them task and when it is given in task, they will look it up on the internet. It is because they are lack of vocabulary......" (Researcher's Translation, P1:40)

In addition, there were some participants show the same opinion about challenges toward students lack of grammar. For instnce, Participant 1 reported that the students were capable of writing a simple sentence but incapable of writing a paragraph. It means that they could not write in the form of paragraph because the sentence is more complicated which the sentences in the form of compound and complex compound. They need to know more rules than simple sentence in order to write a paragraph correctly. When they did not know, the sentences that they wrote were 
incorrect. This situation make the teacher have to find way so that the students can write correctly. Thus, the participant gave permission when the students use internet to write a paragraph.

"Jadi biasannya kalau writing cuma satu kalimat yang singkat saja. Ada subject, verb, object, predicate. Mereka masih bisa ucap, masih bisa tulis.Tapi kalau sudah dalam bentuk paragraph, terpaksa kita beri tugas dan mereka kalau sudah diberi tugas mereka lihat di internet. Karna mereka punya vocabulary kurang sama mereka tidak terlalu paham dengan tenses." (P1:40)

"So usually when write one sentence that short. There are subject, verb, object, and predicate, they still can say and write, but when it is in a paragraph, by force we give them task and when it is given in task form they look on internet. It is because they have lack of vocabulary and they do not understand with tenses." (Researcher's Translation, P1:40)

Additionally, teacher challenges were not only about lacking of vocabulary and grammar, but also lacking the ability in organizing ideas. For instance, Participant 1 explained that they asked the students to use internet. It is because the students could not write a paragraph in English correctly. Thus, through internet, the students could write paragraph correctly.

"Jadi biasannya kalau writing cuma satu kalimat yang singkat saja. Ada subject, verb, object, predicat Mereka masih bisa ucap, masih bisa tulis. Tapi kalau sudah dalam bentuk paragraph, terpaksa kita beri tugas dan mereka kalau sudah diberi tugas mereka lihat di internet." (P1:40).

"Usually, the written sentence is short and has subject, verb, object, and predicate, which still can be said and write by them, but the students have to look up on the internet when we give them tasks in paragraph." (Researcher's transalation, P1:40)

The data above was supported by the result of the researcher's observation to Participant 1 on Monday, $25^{\text {th }}$ November 2019, in X-TKJ class. The participant asked the students to use internet to find simple sentence for them to write. It was also done by Participant 2. Researcher's observation found that they asked the students to write based on the given text or they could find the text in internet as reference for them to write. Researcher's observation on Monday, November $18^{\text {th }}, 2019$, in XI- TAV class:

"Guru meminta siswa untuk membuat text dengan mencari di internet dan mengganti isi text dengan ide mereka. Menurut saya ini bagus karna siswa yang kurang vocabulary dan tidak tau cara menyusun text dengan baik, bisa menyusun dengan baik dengan mengganti beberapa kata dengan menggunakan pengetahuan mereka. Selain itu, alangkah baiknya guru juga memperhatikan teks yang mereka tulis benar-benar pengemabangan dari ide dan pengetahuan mereka atau hanya sekedar menyalin teks yang di dapat di internet."(Fieldnote 2-TAV11/18/2019-10.00)

"The teacher asked the students to make a text based on the text on the internet and change the content of the text according to their ideas. In my personal opinion, this is good because students who lack of vocabulary and do not know how to organize the text well, could organize well with changing some words with their own. Besides that, it is better for the teacher to take notice at the text that students wrote whether It is really emerged from students' ideas and knowledge or just copy of the text that they found on the internet." (Researcher's Translation, Fieldnote 2-TAV-11/18/2019-10.00)

Those participants' responses reported that students are having linguistic problem in vocabulary thus the teachers ask the students to use electronic dictionary, in grammar thus the teachers give correction about grammar in the students writing task, and in organizing ideas thus the teachers give reference text to follow the flow, see text in internet as reference, and letting 
students write with their own words continuously corrected are the way the teacher handle students who have linguistic problem. Nurgiyantoro (2001) said that organizing ideas, lack of vocabulary, and grammatical error is a problem that usually occurred in students writing. This problem makes the run of the teaching and learning process ineffective because the students take a lot of time in finishing the task given by the teacher.

Thus, in teaching writing, the teachers need to find other alternatives so that the students can do the given task well. Hidayanti (2018) found that teachers' get challenges in teaching English writing on students' English competence that the students lack. The teachers were supposed to make the students familiar with the given task which is to adapt to students' knowledge to overcome students' lack of English competence. In addition, giving a writing task that usually happened around the students can make the students be motivated to study. Abid (2020) stated that giving interesting and realistic tasks should involve students in the process of doing it so that they can develop enthusiastic and meaningful qualities, for example, a positive attitude towards writing which is one of the basic principles in improving students writing competence. In addition, giving feedback to students' written tasks can make good students' writing. Alamis (2010) claimed that written feedback encourages the students in improving their own writings.

\section{LEARNING MOTIVATION-RELATED CHALLENGES}

Learning motivation means interest that students have to learn in order to get the knowledge. Thus, if students are less motivated with learning, teachers have to use a technique to motivate the students. Students' lack of motivation in learning English is challenging for the teachers in teaching English. It could be seen from the statement stated by Participant 1. The participant said that she got challenged when teaching English to the students who had no desire in learning it after the second break period. So the participant had to bring back the students' mood to learn by talking about the lesson. The lesson that the participant talked about is based on the students' knowledge. Furthermore, time was given to the students to let them do anything they want before start the lesson.

"Apalagi kalau sudah istirahat itu justru tantangannya, apalagi setelah jam istirahat kedua itu memang minat belajar anak-anak ada yang sudah tidak ada.Jadi tinggal kita guru bagaimana mengembalikan moodnya anak untuk belajar.Saya minta mereka menceritakan tentang materi yang saya ajarkan dengan bahasa mereka. ... Kadang saya beri mereka waktu untuk melakukan apapun tapi jangan ribut.Saya beri mereka kebebasan... Biasa cuma sati jam saya Saya beri mereka waktu untuk santai, setelah itu "sudah!" "iya" "mari kita belajar kembali". Kalau mau dipaksa tinggal kita punya suara yang abis, mereka tinggal ada yang ribut, ada yang melamun, ada yang main." (P1:20)

"The challenge appeared after the break, especially after the second period. There are some students who lost their interest and it is our job as a teacher to bring back students' motivation to learn. I ask them about lesson that I teach with their own words. Sometimes, I give them time to do anything but they need to be silent. I give them an hour of freedom and the second hour is my time to teach. I give them time to relax, after that "finish!" "Yes" "let's study again". Moreover, if we force them, it will only waste our energy because some of them would be noisy, day-dreaming, or playing." (Researcher's Translation, P1:20)

Additional to previous statement, it was also supported by Participant 4. Researcher's observation found that the participant gave a warming up session to the students before start the lesson. Researcher's observation on Thursday, November $21^{\text {th }}, 2019$, in XI-TSM class: 
"Guru meminta siswa siswa untuk mengerakan badan sebelum memulai pelajaran. Semua siswa ikut berpartisipasi dan mereka senang dengan perintah yang guru berikan.Menurut saya ini bagus agar siswa yang mulai lelah dan mengantuk bisa kembali semangat untuk mengikuti pembelajaran."(Fieldnote 4-TSM-11/21/2019-12.14)

"Teacher asked the students to move their body before starting the learning. All students took a part and they were happy with the command that the teacher gave. As far as I can tell, this is good for students who were tired and sleepy and can help them regain their spirit to follow the learning." (Reseaarcher's Translation, Fieldnote 4-TSM-11/21/2019-12.14)

These participants show that students lack motivation in learning English are challenging for teachers because the students do not participate in teaching and learning process. Thus, in teaching, the teachers teach with giving game, ice breaking, and warming up session to make students spirit to study so that the teaching process can run well. Mubarak (2016) stated that a lack of motivation among the students to improve their writing skills is a challenging factor faced by the teachers of writing skills. Thus, in teaching the teachers need to motivate students. Songbatumis (2016) claimed that the way to improve students' motivation in learning English is by giving them motivational feedback. It can be from telling them how good to learn English or using English, every time the teachers meet the students.

\section{CONCLUSION}

This study was conducted at a VHS in Gorontalo, Indonesia. Data were collected using interviews and observations, and analysed using a thematic analysis approach. The study found four themes which address the research question, namely, teaching technique-related challenges, teaching timerelated challenges, linguistics-related challenges, and learning motivation-related challenges. The participants reported that when teaching in the classroom they had to adapt with the students' ability and condition in the classroom using particular techniques, which were sometimes not outlined in their teaching syllabuses. They also have concerns with the limited teaching time, which often impacts on their students' performance when completing writing tasks. This results in the teachers using specific strategy to enable the students finish their writing tasks in the following classroom sessions.

The teachers realise that they have to make the most of their teaching skills to help their students engage in classroom activities, especially to learn to write English better, despite the existence of the different challenges in their classrooms. Even though the teachers are able to cope with particular challenges in their classroom, they still need to explore more strategies in teaching; thus, the teaching and learning process can run effectively. Future studies that looks into students' personal experience when learning to write various English genres during their VHS studies may contribute to existing knowledge on the topic addressed in this present study.

\section{REFERENCES}

Abid. (April, 2015). Learning from lecturers' voices in teaching oral communication in EFL classroom in Indonesia. A paper presented at The Asian Conference on Language Learning, Kobe, Japan. Retrieved from http://repistory.ung.ac.id

Abid. (2020). Revisting issues in English teaching and literature classrooms: Theory, practice, and reflection. Gorontalo: Ideas Publisher.

Alaamri, K.S.S. (2013). Western teachers cultural and linguistic challenges in teaching English language in the classroom. Literacy Information and Computer Journal, 4(3), 1140-1148. Retrieved from 
https://infonomics-society.org/wp-content/uploads/Lijej/Published-Papers/Volume-4-2013/WesternTeachers-Cultural-and-Linguistic-Challenge-in-Teaching-English-Language-in-the -Classroom.pdf

Alamis, M.M.P. (2010). Evaluating students' reactions and responses to teachers' written feedback. Philipine ESL Journal, 5, 40-57. Retrieved from

http://www.google.co.id/search?q=evaluating+students\%27+reactions+and+responses\&client=ucwebb\&channel

Braun, V. \& Clarke, V. (2006). Using thematic analysis in psychology. Qualitative research in psychology, 3(2), 77101. ISSN 1478-0887. Retrieved from

https://www.researchgate.net/publication/235356393_Using_Thematic_Analysis_in_Psychology.pdf

Byrne, D. (1988). Teaching writing skill. London and New York, Longman.

Celce-Murcia, M. (2001). Teaching English as a second or foreign language ( $3^{\text {rd }}$ ed.). Boston, MA: Heinle \& Heinle.

Cotterall, S. and Cohen, R. (2003). Scaffolding for second language writers: producing an academic essay. ELT Journal, 57(2), 158-166.

Departement Pendidikan Nasional (Department of National Education). (2006). Peraturan Mentri Pendidikan Nasional Republik Indonesia, No. 22/2006 Tentang Standar kompetensi lulusan untuk satuan pendidikan dasar dan menengah [The Decree of Government of Republic Indonesia, No. 22/2006 on graduate competencies for elementary and secondary education units]. Jakarta: Departement Pendidikan Nasional

Departemen Pendidikan Nasional (Department of National Education). (2003). Undang-Undang No.20/2003 Tentang Sistem Pendidikan Nasional [The Law of Republic of Indonesia No.20/2003 on National System of Education]. Jakarta: Kementrian Pendidikan Nasional.

Lie, A. (2007). Education policy and EFL curriculum in Indonesia: Between the commitment to competence and quest for higher test scores. TEFLIN Journal V, 18(1), 1-14. Retrieved from http://journal.teflin.org/index.php/journal/article/view/48

Mattarima, K, \& Hamdan, A. R. (2011). Learners' motivation and learning strategies in English Foreign Language (EFI) in Indonesian context. Journal of Edupres, 1, 100-108. Retrieved from https://eprints.utm.my/id/eprint/15931/

Mbato, C.L. (2013). Facilitating EFL learners' self-regulation in reading: implementing a metacognitive approach in an Indonesia higher education context. (Doctoral Disertation), Southern Cross University. Retrieved from https://epubs.scu.edu.au/theses/353/

Nguyen, H. T., Warren, W., \& Fehring, H., (2014). Factors affecting English language teaching and learning in higher education. English Language Teaching, 7(8), 94-105. Retrieved from https://www.researchgate.net/publication/270117978_Factors_Affecting_English_Language_Teaching_and_ Learning_in_Higher_Education.pdf

Nurgiyantoro, B. (2001). Penilaian dalam pengajaran bahasa dan sastra (Assesment in Language and Literature teaching). Yogyakarta : BPFE.

Othman, S.A. (2006). Reorienting Yemeni University Level EFL Writing Instruction to Meet Professional Challenges: An Exploratory Study. (Doctoral Disertation), Central Institute of English and Foreign Languages, Hyderabad. Retrieved from http://hdl.handle.net/10603/185513

Songbatumis, A.M. (2017). Challenging in teaching English faced by English teachers at MTsN Taliwang Indonesia. Journal of foreign language teaching and learning, 2(2), 54-67. Retrieved from

Sulistiyo, U. (2016). Learning English as a foreign language in an Indonesia university: a study of non-english department students preferred activities inside and outside the classroom. Indonesia Journal of English Teaching 5(2), 1-26. DOI: 10.15642/ijet2.2016.5.1.1-26

Suryati, N. (2013). Developing an effective classroom interaction framework to promote lower secondary school students' English communicative competence in Malang, East Java, Indonesia. (Unpublish Dissertation), The University of Newcastle. Retrieved from https://nova.newcastle.edu.au/vital/access/manager/Repository/uon:13587?view

Wilson, H. (2014). Turning of the school-to-prison pipeline. Reclaiming children and youth, 23(1), 49-53. Retrieved from http://www.clark.edu/academics/programs_old/english/englishplacement/documents/098commonreading.pdf

Yuwono, G. (2005). English language teaching in Decentralised Indonesia: voices from the less privileged schools. Paper presented at AARE 2005 International Education Research Conference, 1-19. Retrieved from https://www.aare.edu.au/data/publications/2005/yuw05050.pdf 